\title{
DEVELOPMENT OF MICRO, SMALL AND MEDIUM ENTERPRISES RATTAN WOVEN CRAFTS IN CENTRAL KALIMANTAN, INDONESIA
}

\author{
lin Nurbudiyani \\ Sonedi \\ Endang Sri Suyati \\ Mohammad Rizki Fadhil \\ Pratama* \\ Universitas Muhammadiyah \\ Palangkaraya, Palangka Raya, \\ Central Kalimantan, Indonesia \\ *email: \\ m.rizkifadhil@umpalangkaraya.ac.id
}

\section{Keywords:}

Central Kalimantan

Rattan woven craft

MSME

Accepted

January 2019

Published

June 2019

\begin{abstract}
This study discusses the development of small and medium micro enterprises (MSMEs) in Central Kalimantan with rattan woven craft industries being used as samples to represent other MSME sectors. The purpose of this study is to describe the improvement in the performance and strategy of the MSME group covering various aspects such as job training, capital support, equipment/technology assistance, and access to information and communication. The findings of this study indicate that the development of MSMEs carried out by regional governments in Central Kalimantan has gone in the right direction, with several factors still making improvements possible. Support in the form of training should be conducted regularly and scheduled with the topic of continuous training and productive participants. Aid in the form of equipment requires periodic evaluations, such as a reward-punishment system for business groups that have received various support to ensure the support provided is on target. Another strategy is to form the centre of the MSME industry in the Capital of the Province, to facilitate the access of tourists who just want to visit looking for typical Central Kalimantan souvenirs. The easiest way to do this now is to implement a movement of love for standard Central Kalimantan handicraft products to be displayed in various offices, offices, and government agencies as well as different infrastructure and public facilities.
\end{abstract}

(C) 2019 The Authors. Published by Institute for Research and Community Services Universitas Muhammadiyah Palangkaraya. This is Open Access article under the CC-BY-SA License (http://creativecommons.org/licenses/by-sa/4.0/). DOI: https://doi.org//0.33084/anterior.v18i2.533.

\section{INTRODUCTION}

The dynamics of socio-cultural change and global changes have a very broad influence on the policies of the government of the Republic of Indonesia. The aforementioned influences in general are demands on improving the quality of human resources (HR) that have competitive ability and comparative ability to realize the achievement of national development goals and fulfill the demands of global competition in all fields, including in the economic sector which aims to improve people's welfare (Baharuddin, 20I5). Many aspects need to be developed or updated in the economic field, for example through the development of craft industries and Micro, Small and Medium Enterprises (MSMEs). The development of MSMEs and cooperatives has great and strategic potential in increasing national economic activities, including providing domestic goods and services (Irawan, 20I5). Small businesses are one of the pillars of economic development that is directly fostered and protected by the government. Small businesses have the potential to develop so they are able to plunge into the global economy. The existence of business resilience and independence, the people's economy has prospects in the free market competition in the future if serious guidance is carried out by the central and regional governments (Wardani, 20I7).

Micro, Small and Medium Enterprises have a very important role in the Indonesian economy, playing a very potential role in increasing new supply and competition, developing technology, creating new markets, increasing employment opportunities and production output. The MSME-based economy is better because this business absorbs a lot of labor, relatively small capital. Apart from that, MSMEs are also able to 
increase creativity for people who want to have more income, while also being able to become a characteristic of an area's identity from its production (Gunartin, $2017)$.

In the dynamics of economic development in Indonesia MSMEs are always described as a sector that has a very important role, because most of the population is low educated and lives in business activities both in the traditional and modern sectors (Hapsari et al., 20l4). There are several strong reasons why MSMEs need to be developed in Indonesia, including:

I. Small businesses absorb a lot of labor, with the development of MSMEs that will have a positive impact on increasing the number of workers and reducing the number of poverty.

2. Equity in the distribution of development, the location of many MSMEs in rural areas and using local natural resources.

3. Equity in income distribution, MSMEs are very competitive with market patterns, there is no monopoly and easy to enter (Setyanto et al., 2015; Nirwana et al., 2017).

In addition, there are several reasons why MSMEs are able to survive, namely because they have different strengths than other types of businesses. The power in question is as follows:

I. Employment provider

2. New sources of entrepreneurship

3. Has a unique market segment

4. Carry out simple and flexible management of market changes

5. Utilizing natural resources around

6. Has the potential to develop (Sulastri, 2016).

The government in this case continues to maintain the business climate so that MSMEs continue to survive. Surviving does not mean not doing development. Empowerment is always carried out by the central government, regional governments, communities, and the business world as a form of strengthening MSME business. Business people usually hunt which institutions are able to provide assistance in the form of business capital loans. Therefore, they looked at cooperatives, because currently many government programs are rolled out through this cooperative institution (Putra, 2015).

But all of that does not necessarily run smoothly, the problem is certainly there, the problem faced does not mean that it cannot be overcome by these business people, only need to work with the government so that it can be overcome. This is also in accordance with the direction of fiscal 2014, which is one of the goals to meet the MSMEs towards a better direction. The government also realizes the importance of MSMEs, not only as one of the important sources of employment and income, which in turn means one of the important sources of poverty reduction, but also as a source of GDP growth (Mokalu, 2016).

The populist-based handicraft industry is one of the potential assets in the context of regional economic development. Local MSME-based industries can be developed with relatively little capital, the production process can be carried out together in small groups with simple technology, raw materials can be extracted from local natural resources, and the workforce can be fostered from the local area without requiring too much external power. The more centers of MSMEs can be developed in regions producing local resources, the greater the possibility of economic growth and prosperity in the area, especially if the commodities produced are able to penetrate the export market on a large scale. The empowerment of MSMEs for folk crafts should ideally be one of the main priorities in the development of the local economy (Utama \& Darwanto, 2013).

Various government efforts have been made to empower small and medium enterprises, both in terms of capital, skills, equipment and access to information 
and communication. If seen from the number of MSMEs developing in Central Kalimantan Province which reached 3I,033 units, the supply of handicrafts from local products should have been fulfilled. From the preliminary information it turns out that the problems that are often faced in empowering small and medium enterprises, including for rattan product processing businesses, are quite numerous, including the following:

I. Workers or managers are limited

2. Management skills are uneven

3. Cooperation between MSMEs has not been developed

4. The use of equipment that is still simple

5. MSMEs are still part-time work (Widyaningrum et al., 2003).

One potential folk handicraft product that can be developed through various centers or groups of MSMEs in Indonesia, especially in Central Kalimantan Province, is rattan-based folk crafts with export quality. This product is one of the important export commodities to be developed, because the raw material is very abundant. At present $85 \%$ of the world's rattan raw materials are imported from Indonesia, especially Central Kalimantan and South Kalimantan. Besides that, many rattan farmers who are impatient are important to get money quickly so that they sell raw rattan which is relatively much lower in price than well-produced rattan products (Kartini et al., 2019; Maimunah, 2017; Wahdah \& Amalia, 2016).

The purpose of this study is to examine and analyze the condition of MSMEs, especially rattan woven crafts in Central Kalimantan Province. With the intervention of the government with the hope that the rattan handicrafts SMEs are not only large in terms of quantity but also in quality, which is able to compete with other large businesses in Central Kalimantan Province. Besides that, it is also discussed in detail about what are the elements in the management of rattan woven furniture MSMEs in Central Kalimantan that can be optimized based on analysis of Strengths, Weaknesses, Opportunities and Threats (SWOT).

\section{METHODS}

The approach method used is qualitative, namely the researchers describe the data obtained from the centers of rattan handicrafts in MSMEs in Central Kalimantan. The focus of the research is the performance of rattan handicraft UMKM centers sourced from the aspects of training, capital, equipment, and access to information and communication in each group of rattan craft centers. Data collected and analyzed include training on MSME work, data on working capital support, data on technology/equipment assistance, and data on information access and communication (Wardani, 20l7).

Research begins with the management of permits with related agencies, followed by gathering information from predetermined informants, and ending with an analysis of the data collected. The approach used in this study is to gather information from rattan handicraft business actors on managerial aspects in the rattan handicraft industry (Masturi, 2010). The choice of sample itself is based on various considerations such as track record, production capacity, turnover, number of employees, continuity of production, and recommendations from relevant government offices.

\section{RESULTS AND DISCUSSION}

The area that was the location of the research location was chosen based on several considerations, such as the existence of rattan woven craftsmen who were the object of research, where the research location must have a large number of rattan handicraft business groups not only dominated by large business groups. Based on these considerations, several regions were chosen as the research sites, namely Palangka Raya City 
and Pulang Pisau District. The information collected is sorted and obtained various information as follows:

I. The types of rattan handicraft products that are most widely produced and sold in large quantities in Central Kalimantan are dominated by accessories such as bags, hats, and lawung.

2. The various products sold at prices above Rp. 100,000 , except for small knick-knacks such as key chains.

3. The annual income range of each craftsman is very far different, where there are craftsmen who can get a net income of up to Rp. 50,000,000, but some are not even up to Rp. 500,000 a year.

4. All business groups that have become resource persons have received various assistance from the local government through related agencies, such as providing training, providing production equipment such as sewing machines, and participating in various exhibitions at the regional, national, and even international levels.

5. The various supports received by each business group in fact are not directly proportional to the increase in business capacity of each group.

6. Interestingly, craftsmen who are located in the central area of the specialty rattan handicraft industry do not always have a better income than craftsmen located in various places.

7. In general, the average income obtained by craftsmen in Palangka Raya City is higher than those in comparison locations, namely Pulang Pisau Regency. The distance factor from the entrance access to Central Kalimantan is thought to have an important role.

8. However, the existence of industrial centers such as those in Pulang Pisau District still provides strategic advantages where the gathering of craftsmen in one place makes it easy for travelers to look for certain handicraft products.
The types of rattan woven handicraft products produced in Central Kalimantan are presented in Figure I, where the sample data collection process is shown in Figure 2.

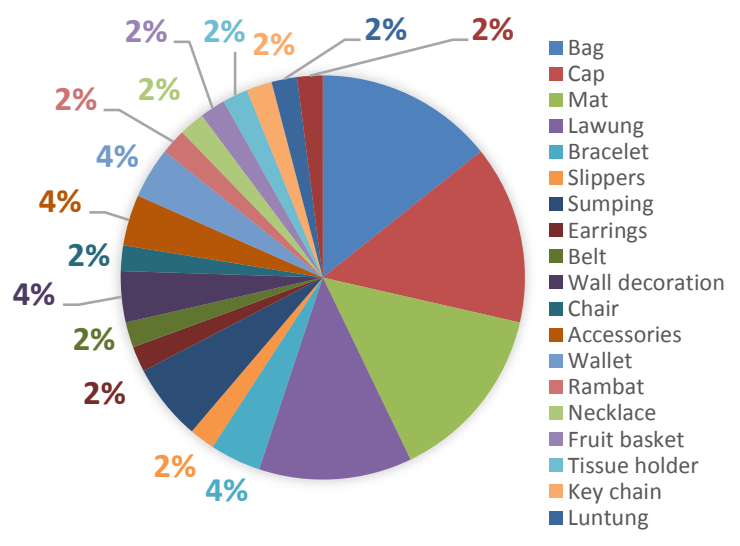

Figure I. Types of Rattan Woven Craft Products in Central Kalimantan

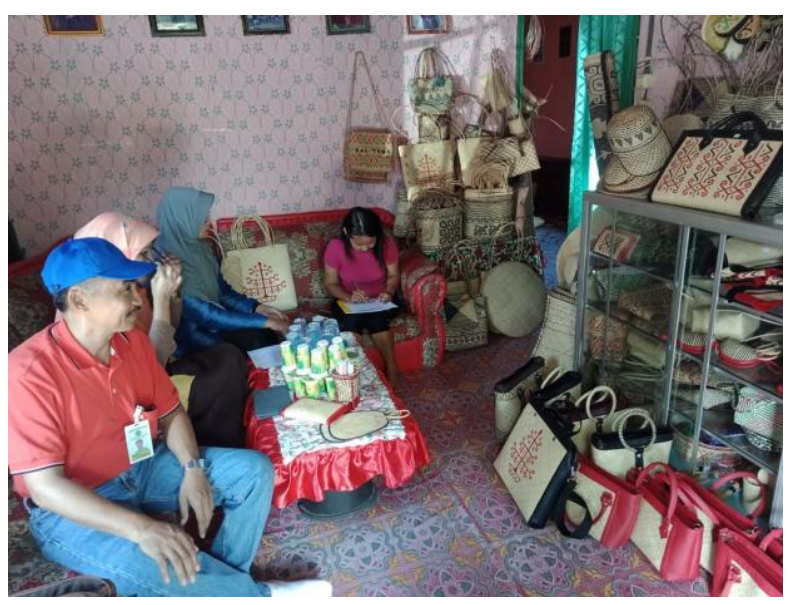

Figure 2. Interview with rattan handicraft business players

All groups of craftsmen who were used as resource persons were given several questions related to aspects that affect the quantity and quality of the production process of rattan woven crafts made, including some technical matters that influence the course of the production process. The interview session was divided into 2 sessions, namely interviews with the group leaders of craftsmen and representatives of members from each group. Through the results of the interviews obtained some information which is then collected and sorted as shown in Tables I and 2. 
Table I. Interview results from the Chairperson of the Craftsmen Group

\begin{tabular}{|c|c|c|}
\hline Number & Form questions & Digest answer \\
\hline I & $\begin{array}{l}\text { How have you } \\
\text { seen artisans in } \\
\text { your business } \\
\text { unit so far? }\end{array}$ & $\begin{array}{l}\text { - Generally all group leaders } \\
\text { stated that craftsmen } \\
\text { employees who worked in } \\
\text { each business group had good } \\
\text { enthusiasm, especially } \\
\text { members who were relatively } \\
\text { young. } \\
\text { - The high enthusiasm of each } \\
\text { member is mainly shown in } \\
\text { the business groups that make } \\
\text { rattan handicraft business } \\
\text { their main source of income. } \\
\text { Creativity shown by young } \\
\text { group members can inspire } \\
\text { other older members. } \\
\text { Even so, there are still some } \\
\text { group leaders who state that } \\
\text { there are members of their } \\
\text { group who need guidance, } \\
\text { especially for members of the } \\
\text { young and minimal skill group } \\
\text { of craftsmen. }\end{array}$ \\
\hline 2 & $\begin{array}{l}\text { What steps have } \\
\text { you taken to } \\
\text { improve the skills } \\
\text { of rattan } \\
\text { craftsmen in your } \\
\text { business unit? }\end{array}$ & $\begin{array}{l}\text { - In a compact manner the } \\
\text { chairmen of the craftsmen } \\
\text { group routinely gave } \\
\text { motivation to the craftsmen, } \\
\text { especially those who seemed } \\
\text { to have less enthusiasm. } \\
\text { - Poor communication with } \\
\text { craft members is often a } \\
\text { constraining obstacle in the } \\
\text { production process, especially } \\
\text { if there are craftsmen who are } \\
\text { not pleased and become lazy } \\
\text { to do their jobs. } \\
\text { - Some group leaders take the } \\
\text { initiative to carry out } \\
\text { additional training to their } \\
\text { group members by } \\
\text { collaborating with related } \\
\text { agencies in each region. } \\
\text { The training is given both } \\
\text { directly and indirectly, it can } \\
\text { be in the form of training } \\
\text { directly or indirectly by } \\
\text { providing reading material } \\
\text { related to the production } \\
\text { process of rattan woven skills. } \\
\text { The training most often given } \\
\text { is mainly for sewing skills using } \\
\text { sewing machines for business } \\
\text { groups that already have } \\
\text { sewing machines, both from } \\
\text { their own capital and } \\
\text { assistance from the local } \\
\text { government. } \\
\text { In addition to providing } \\
\text { motivation and training, the } \\
\text { group leaders also provide } \\
\text { specific directions to maintain } \\
\text { the quality of the products } \\
\text { broduced so that they can } \\
\text { buss groups. }\end{array}$ \\
\hline 3 & $\begin{array}{l}\text { If it has ever been } \\
\text { done, what is } \\
\text { your response to } \\
\text { the work training } \\
\text { program by the } \\
\text { Regional } \\
\text { Government }\end{array}$ & $\begin{array}{l}\text { - All business groups used as } \\
\text { resource persons have } \\
\text { received job training carried } \\
\text { out by each local government. } \\
\text { - The training program was } \\
\text { welcomed by each group } \\
\text { leader and each group }\end{array}$ \\
\hline
\end{tabular}

\begin{tabular}{|c|c|c|}
\hline & $\begin{array}{l}\text { from related } \\
\text { agencies for } \\
\text { craftsmen in your } \\
\text { business unit? }\end{array}$ & $\begin{array}{l}\text { expected the training } \\
\text { activities to be held regularly } \\
\text { every year. } \\
\text { - Generally the training } \\
\text { programs gave a good } \\
\text { response from the craftsmen, } \\
\text { where the craftsmen admitted } \\
\text { that they really needed the } \\
\text { training to improve the skills } \\
\text { of each group of craftsmen. } \\
\text { - Even so, some craftsmen } \\
\text { claimed to be dissatisfied with } \\
\text { the training activities given } \\
\text { because the time was } \\
\text { relatively short so it was not } \\
\text { too useful for craftsmen, } \\
\text { especially from a group of } \\
\text { craftsmen who had quite a } \\
\text { large number of employees. } \\
\text { - In addition, the craftsmen also } \\
\text { hoped that the training } \\
\text { activities would be } \\
\text { accompanied by coaching } \\
\text { activities as a follow-up to the } \\
\text { training activities. }\end{array}$ \\
\hline 4 & $\begin{array}{l}\text { If ever, do you } \\
\text { see any changes } \\
\text { and } \\
\text { improvements in } \\
\text { rattan craftsmen } \\
\text { in your business } \\
\text { unit? }\end{array}$ & $\begin{array}{l}\text { - The business group leaders } \\
\text { agreed that the training } \\
\text { directly had a positive impact } \\
\text { on improving the quality and } \\
\text { quantity of products made by } \\
\text { rattan craftsmen. } \\
\text { - Not only that, the striking } \\
\text { change is from the motivation } \\
\text { of each craftsman who wants } \\
\text { to change to become more } \\
\text { advanced so that the products } \\
\text { produced can be sold at } \\
\text { higher prices. } \\
\text { - The main motivation for these } \\
\text { changes is to improve welfare } \\
\text { to increase the economy of } \\
\text { his family. } \\
\text { These changes unfortunately } \\
\text { do not always run the same in } \\
\text { every business group where } \\
\text { there are always I or } 2 \text { people } \\
\text { who are not significantly } \\
\text { motivated and only consider } \\
\text { the training to be just a filler } \\
\text { of leisure time. }\end{array}$ \\
\hline 5 & $\begin{array}{l}\text { If there is no or } \\
\text { only a slight } \\
\text { change and } \\
\text { improvement in } \\
\text { the rattan } \\
\text { craftsman, what } \\
\text { is the cause? }\end{array}$ & $\begin{array}{l}\text { - There are some craftsmen } \\
\text { who have not undergone too } \\
\text { many changes in terms of } \\
\text { increasing the quality and } \\
\text { quantity of production, even } \\
\text { though there are not many } \\
\text { craftsmen. } \\
\text { - There are several factors that } \\
\text { are suspected to be the cause } \\
\text { of resistance from the } \\
\text { craftsmen, one of the main } \\
\text { factors is that the training } \\
\text { carried out is incidental and } \\
\text { not regularly scheduled, so } \\
\text { that the craftsmen consider } \\
\text { this to be not serious in } \\
\text { increasing production. } \\
\text { The rest did not find } \\
\text { significant problems in the } \\
\text { implementation of the training } \\
\text { activities, especially in terms } \\
\text { of technical implementation. }\end{array}$ \\
\hline 6 & $\begin{array}{l}\text { What are the } \\
\text { forms }\end{array}$ & $\begin{array}{l}\text { - On average each business } \\
\text { group receives } 2 \text { types of } \\
\text { coaching and mentoring }\end{array}$ \\
\hline
\end{tabular}




\begin{tabular}{|c|c|c|c|}
\hline & $\begin{array}{l}\text { coaching and } \\
\text { assistance? }\end{array}$ & - & $\begin{array}{l}\text { activities during the training } \\
\text { process, namely coaching in } \\
\text { the production process and in } \\
\text { marketing matters. } \\
\text { Guidance in the production } \\
\text { process is carried out in two } \\
\text { stages, namely the provision } \\
\text { of assistance in the form of } \\
\text { production equipment such as } \\
\text { sewing machines, and the } \\
\text { implementation of training on } \\
\text { how to use sewing machines } \\
\text { to produce rattan handicrafts. } \\
\text { While marketing assistance is } \\
\text { carried out by including the } \\
\text { work of the business group in } \\
\text { various exhibitions of typical } \\
\text { Central Kalimantan crafts } \\
\text { both inside and outside the } \\
\text { region. }\end{array}$ \\
\hline 7 & $\begin{array}{l}\text { If the rattan } \\
\text { craftsman in your } \\
\text { business unit is } \\
\text { not maximally } \\
\text { creative and } \\
\text { innovates the } \\
\text { product, it is not } \\
\text { timely to } \\
\text { complete the } \\
\text { work on demand, } \\
\text { and the quality is } \\
\text { not in } \\
\text { accordance with } \\
\text { market demand } \\
\text { standards, do you } \\
\text { take the initiative } \\
\text { to work with } \\
\text { other business } \\
\text { units? }\end{array}$ & - & $\begin{array}{l}\text { Most craftsmen stated that to } \\
\text { overcome various obstacles in } \\
\text { the production process by } \\
\text { cooperating with other rattan } \\
\text { handicraft business groups. } \\
\text { Generally the collaboration is } \\
\text { intended as a form of } \\
\text { transplantation (detachment) } \\
\text { for transfer of skills between } \\
\text { craftsmen with high skills with } \\
\text { those who are still relatively } \\
\text { beginners. } \\
\text { Other cooperation is in the } \\
\text { form of work orders in the } \\
\text { form of tolls, where groups } \\
\text { with excess orders will hand } \\
\text { over orders to other groups } \\
\text { that are free and there are no } \\
\text { orders. } \\
\text { Even so, there are only } \\
\text { business groups that choose } \\
\text { not to cooperate with other } \\
\text { groups to complete orders } \\
\text { that are full and have to spur } \\
\text { the production of group } \\
\text { members in order to } \\
\text { complete orders on time. } \\
\text { Not only that, if the target of } \\
\text { the order is not fulfilled on } \\
\text { time, there is a group of } \\
\text { craftsmen who choose to } \\
\text { deduct honorarium from } \\
\text { group members who cannot } \\
\text { complete the order on time as } \\
\text { a form of punishment against } \\
\text { members of the group. }\end{array}$ \\
\hline
\end{tabular}

Table 2. Results of Interviews from Members of the Craftsman Group

\begin{tabular}{|c|c|c|}
\hline Number & Form questions & Digest answer \\
\hline I & $\begin{array}{l}\text { Have you been able } \\
\text { to make } \\
\text { varied/varied crafts } \\
\text { and develop design } \\
\text { innovations (new } \\
\text { models) according } \\
\text { to demand? If yes, } \\
\text { how do you do that } \\
\text { and if not, why } \\
\text { can't you do it? }\end{array}$ & $\begin{array}{l}\text { - Most craftsmen state that they } \\
\text { can innovate and develop designs } \\
\text { and models that are in } \\
\text { accordance with the demands of } \\
\text { the customers. } \\
\text { - The innovation that was carried } \\
\text { out came from the personal } \\
\text { ideas of each craftsman who was } \\
\text { inspired by the surrounding } \\
\text { environment as well as the } \\
\text { inspiration of others. }\end{array}$ \\
\hline
\end{tabular}

\begin{tabular}{|c|c|c|}
\hline & & $\begin{array}{l}\text { - There are just a few craftsmen } \\
\text { who choose not to innovate and } \\
\text { maintain the motives, designs, } \\
\text { and models that have been } \\
\text { produced for generations. } \\
\text { - The reason for not doing } \\
\text { innovation is to maintain the } \\
\text { values of traditional cultural } \\
\text { heritage that must be preserved, } \\
\text { besides indeed because the } \\
\text { capabilities of these craftsmen } \\
\text { are not capable of carrying out } \\
\text { innovation. }\end{array}$ \\
\hline 2 & $\begin{array}{l}\text { Have you been able } \\
\text { to make crafts on } \\
\text { time as requested? } \\
\text { If yes, how do you } \\
\text { do that and if not, } \\
\text { why can't you do it? }\end{array}$ & $\begin{array}{l}\text { - All craftsmen interviewed stated } \\
\text { that they could not complete the } \\
\text { order on time, generally they } \\
\text { could complete the order before } \\
\text { the allotted time. } \\
\text { - The way the craftsmen to } \\
\text { complete orders on time is by } \\
\text { completing orders based on the } \\
\text { order of entry of orders and } \\
\text { delaying the completion of } \\
\text { orders, the time of completion is } \\
\text { still quite long. } \\
\text { - For groups of craftsmen who } \\
\text { have many employees, the } \\
\text { division of tasks is made easier } \\
\text { because the division of tasks is } \\
\text { given more freely. } \\
\text { - As for the smaller group of } \\
\text { craftsmen, members work harder } \\
\text { to complete orders. }\end{array}$ \\
\hline 3 & $\begin{array}{l}\text { Have you been able } \\
\text { to make good } \\
\text { quality crafts and } \\
\text { have been } \\
\text { recognized as good } \\
\text { as you have } \\
\text { requested? If yes, } \\
\text { how do you do that } \\
\text { and if not, why } \\
\text { can't you do it? }\end{array}$ & $\begin{array}{l}\text { - The craftsmen who were } \\
\text { speakers were confident enough } \\
\text { to state that the handicraft } \\
\text { products they produced had } \\
\text { good quality and could satisfy the } \\
\text { order giver. } \\
\text { - One indicator of their belief is } \\
\text { that until now they have never } \\
\text { received a complaint because the } \\
\text { product produced is not in } \\
\text { accordance with what was } \\
\text { ordered, some even claimed to } \\
\text { have been given tips as a bonus } \\
\text { because the products produced } \\
\text { exceeded the expectations of the } \\
\text { order giver. } \\
\text { - Generally the craftsmen say they } \\
\text { are worried that they will make } \\
\text { the order giver not satisfied if the } \\
\text { product produced is not qualified, } \\
\text { which can affect the perceptions } \\
\text { of the order giver on the } \\
\text { professionalism of the work of } \\
\text { their business group. }\end{array}$ \\
\hline 4 & $\begin{array}{l}\text { To improve your } \\
\text { skills as a rattan } \\
\text { craftsman, have } \\
\text { you ever received } \\
\text { job training, capital } \\
\text { support, } \\
\text { technology } \\
\text { assistance, and } \\
\text { access to } \\
\text { information from } \\
\text { other business } \\
\text { units or related } \\
\text { government and } \\
\text { agencies? explain } \\
\text { Please } \\
\text { from: } \\
\text { - Training } \\
\text { - Capital support } \\
\end{array}$ & $\begin{array}{l}\text { - Of the } 32 \text { resource persons } \\
\text { interviewed, most of them knew } \\
\text { that their business groups had } \\
\text { received various assistance from } \\
\text { other business units and the local } \\
\text { government through the relevant } \\
\text { agencies and had received direct } \\
\text { training. } \\
\text { - For job training, craftsmen get } \\
\text { training in production and } \\
\text { marketing. } \\
\text { - Examples of training that have } \\
\text { been obtained include training in } \\
\text { rattan craft design provided by } \\
\text { the Integrated Business Service } \\
\text { Center (PLUT) of the Central } \\
\text { Kalimantan Micro, Small and }\end{array}$ \\
\hline
\end{tabular}




- Technology/equip
ment support
- Access to
information and
communication

Medium Enterprises Cooperative which was held for 2 days.

- Assistance in the form of capital support is generally unknown to the craftsmen, because the capital assistance is given directly to the group leader so that only a few members of the craftsman know that they have received capital assistance from other parties.

- For assistance in the form of equipment support, most craftsmen know if they get help, because assistance is generally provided in the form of equipment / assets in the form of sewing machines that are directly used by craftsmen.

- Sources of assistance in the form of equipment obtained vary, some from government institutions such as Bank Indonesia and from the regional government through related agencies.

- For support in the form of access to information and communication, it is given in the form of invitations to participate in various exhibition activities at the local and national levels.

- Support for access to information that has been obtained from the Cooperative Office of each region as well as from PLUT Central Kalimantan.

If it has ever been done, how is the response or impact on you on the job training program of the local government or related agencies, for training in your business unit?

Please explain

from:

- Frequency of job

training

- Capital support

- Technology assistance

- Access to information and communication given directly to the group leader
The number and frequency of job training obtained from each craftsman varies greatly because the self-selected speakers are a combination of senior and junior employees.

- On average, all craftsmen who became speakers and have received training have received training 4 to 5 times since they first became craftsmen.

- As mentioned earlier, assistance in the form of capital support was not known by the craftsmen, because the capital assistance was so that only a handful of craftsmen knew that they had received capital assistance from other parties.

- The thing that is known by craftsmen is that their business groups have received capital support from other parties, without knowing the nominal assistance received.

- Assistance in the form of equipment received is sewing machines whose numbers vary between business groups, where there are those who obtain in large quantities but there are also business groups that have not received any equipment assistance.

- Information and communication access assistance is mainly given by the local Cooperative and UMKM Office in the form of

\begin{tabular}{|c|c|c|}
\hline & & $\begin{array}{l}\text { information as well as invitations } \\
\text { to participate in various } \\
\text { exhibitions and special events for } \\
\text { other MSME actors. } \\
\text { - In addition, information is also } \\
\text { obtained from other institutions } \\
\text { related to MSMEs such as PLUT } \\
\text { Central Kalimantan and those } \\
\text { from fellow rattan craftsmen. }\end{array}$ \\
\hline 6 & $\begin{array}{l}\text { If ever, do you see } \\
\text { any changes and } \\
\text { improvements in } \\
\text { yourself in } \\
\text { producing rattan } \\
\text { crafts in your } \\
\text { business unit }\end{array}$ & $\begin{array}{l}\text { - Generally most craftsmen say } \\
\text { that they see a significant change } \\
\text { in their respective craftsmen after } \\
\text { obtaining various supports from } \\
\text { other parties. } \\
\text { - The majority said that the } \\
\text { increase occurred in terms of } \\
\text { quality because the craftsmen } \\
\text { who had received design training } \\
\text { and support in the form of sewing } \\
\text { machines could complete the } \\
\text { production process faster so that } \\
\text { the products produced became } \\
\text { more numerous. } \\
\text { - Other changes occur in terms of } \\
\text { quality where the craft products } \\
\text { they produce become smoother } \\
\text { and not easily damaged, so the } \\
\text { selling price of their products also } \\
\text { increases. }\end{array}$ \\
\hline 7 & $\begin{array}{l}\text { If there are no or } \\
\text { only a few changes } \\
\text { and improvements } \\
\text { in yourself, what is } \\
\text { the cause? }\end{array}$ & $\begin{array}{l}\text { - There are some craftsmen who } \\
\text { claim that they have not } \\
\text { experienced a significant increase } \\
\text { after obtaining these various } \\
\text { supports, especially senior } \\
\text { craftsmen who are accustomed } \\
\text { to producing without the help of } \\
\text { modern equipment such as } \\
\text { sewing machines. } \\
\text { - Generally senior craftsmen } \\
\text { stated that they chose not to use } \\
\text { the help of modern equipment } \\
\text { because they believed that the } \\
\text { use of sewing machines would } \\
\text { cause the products they made to } \\
\text { be subtle and they trusted the } \\
\text { results of their work with their } \\
\text { hands. } \\
\text { In addition, senior craftsmen } \\
\text { chose not to develop the designs } \\
\text { and models they made to } \\
\text { maintain the design of ancestral } \\
\text { heritage that had been maintained } \\
\text { for generations. } \\
\text { - Another reason why they do not } \\
\text { develop designs and models is } \\
\text { because they are generally } \\
\text { difficult to follow the } \\
\text { development of designs that } \\
\text { require the skill of using sewing } \\
\text { machines and other modern } \\
\text { equipment, so that the resulting } \\
\text { design tends to be monotonous. }\end{array}$ \\
\hline 8 & $\begin{array}{l}\text { If you are not } \\
\text { maximally creating } \\
\text { and innovating the } \\
\text { product, it is not } \\
\text { timely to complete } \\
\text { the work on } \\
\text { demand and } \\
\text { product quality is } \\
\text { not in accordance } \\
\text { with market } \\
\text { demand standards, } \\
\text { are you } \\
\text { sanctioned? }\end{array}$ & $\begin{array}{l}\text { - On average, the craftsmen who } \\
\text { were the speakers said that there } \\
\text { was no agreement to impose } \\
\text { sanctions from group leaders if } \\
\text { there were defects in the } \\
\text { products they produced or their } \\
\text { workmanship exceeded the } \\
\text { specified time. } \\
\text { - Some craftsmen say that there is } \\
\text { a warning given by the group } \\
\text { leader if the product they } \\
\text { produce has defects or other } \\
\text { disadvantages }\end{array}$ \\
\hline
\end{tabular}


Even so, they realize that workmanship that is careless and not quality or workmanship exceeding the target time can cause the customers' trust to decrease, so it is feared that in the future they will not get more orders.

The results of the interviews that have been collected are then analyzed according to the SWOT analysis to find out what strategies can be done to develop micro, small and medium enterprises based on rattan woven crafts in Central Kalimantan. The results of the analysis will then become the starting point in the preparation of the brief policy which will be a recommendation for the Central Kalimantan Regional Government for business, micro, small and medium business development especially for rattan handicraft products. The following is a SWOT analysis that has been carried out for the results of interviews with both agency representatives related to each region, group leaders and representatives of group members from each craftsman, as shown in Table 3.

Table 3. SWOT Analysis of Interview Results from Chairmen and Members of the Craftsman Group

\begin{tabular}{|c|c|c|}
\hline & Helpful & Harmful \\
\hline Internal & 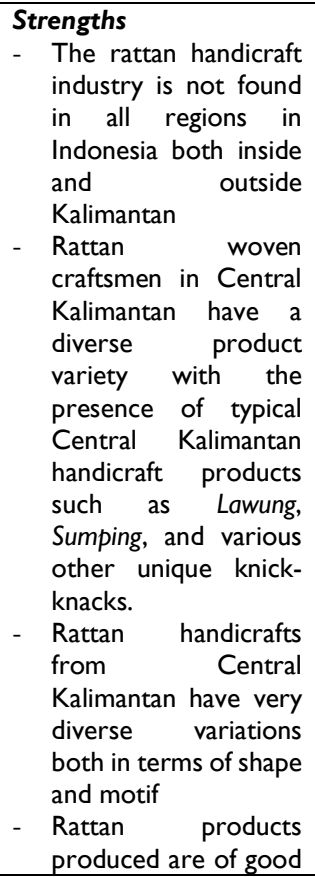 & $\begin{array}{l}\text { Weaknesses } \\
\text { - The process of } \\
\text { processing } \\
\text { rattan crafts } \\
\text { requires high } \\
\text { skills and } \\
\text { expertise and } \\
\text { requires training } \\
\text { for some time } \\
\text { - Sales of rattan } \\
\text { handicraft } \\
\text { products do not } \\
\text { occur every day } \\
\text { - The form of } \\
\text { processed rattan } \\
\text { handicrafts is } \\
\text { relatively slow to } \\
\text { develop so that } \\
\text { the models and } \\
\text { designs tend to } \\
\text { be monotonous } \\
\text { - Distribution of } \\
\text { handicraft } \\
\text { products only } \\
\text { produced tends } \\
\text { not to be broad, } \\
\text { mostly on onlo }\end{array}$ \\
\hline
\end{tabular}

\begin{tabular}{|c|c|c|}
\hline & $\begin{array}{l}\text { quality and can be sold } \\
\text { at high prices, so they } \\
\text { can be the main } \\
\text { livelihood of the } \\
\text { craftsmen } \\
\text { - Rattan handicraft } \\
\text { products are durable } \\
\text { and can be stored for } \\
\text { a long time without } \\
\text { damage so there is no } \\
\text { need to worry about } \\
\text { losing because the } \\
\text { stored product does } \\
\text { not expire } \\
\text { The rattan handicraft } \\
\text { industry is a potential } \\
\text { field to be developed } \\
\text { especially in Central } \\
\text { Kalimantan }\end{array}$ & $\begin{array}{l}\text { marketed in the } \\
\text { Central } \\
\text { Kalimantan } \\
\text { environment, } \\
\text { not reaching } \\
\text { other areas } \\
\text { - Rattan handicraft } \\
\text { products are } \\
\text { generally large } \\
\text { enough so that } \\
\text { they cannot be } \\
\text { marketed in } \\
\text { large quantities } \\
\text { without using } \\
\text { large vehicles for } \\
\text { transportation } \\
\text { - The number of } \\
\text { rattan handicraft } \\
\text { business groups } \\
\text { in Central } \\
\text { Kalimantan is } \\
\text { relatively large } \\
\text { while the local } \\
\text { market itself is } \\
\text { quite small and } \\
\text { limited so } \\
\text { marketing on } \\
\text { cannot rely on } \\
\text { local and } \\
\text { domestic markets only } \\
\text { med }\end{array}$ \\
\hline External & 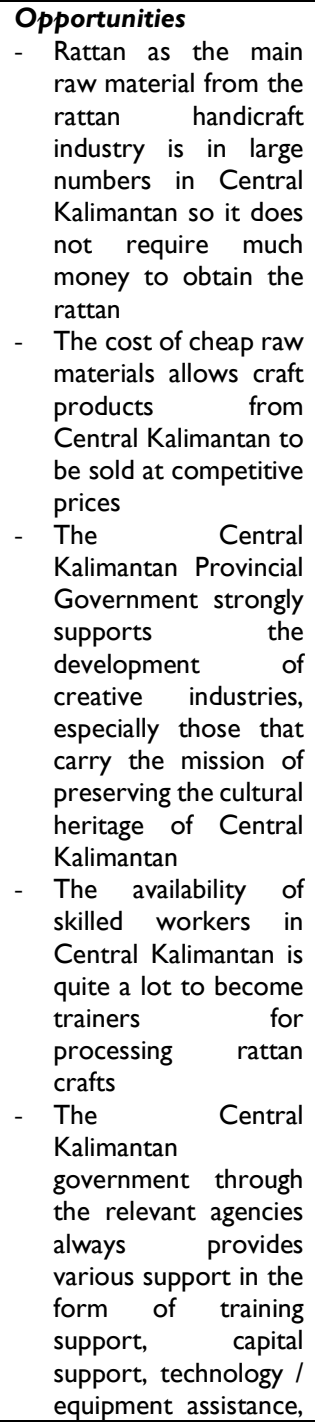 & $\begin{array}{l}\text { Threats } \\
\text { - Rattan } \\
\text { handicrafts are } \\
\text { not only } \\
\text { synonymous } \\
\text { with Central } \\
\text { Kalimantan, } \\
\text { making it difficult } \\
\text { to become a } \\
\text { typical Central } \\
\text { Kalimantan } \\
\text { product } \\
\text { branding } \\
\text { - Rattan } \\
\text { processed } \\
\text { handicraft } \\
\text { products are still } \\
\text { underestimated } \\
\text { by some people } \\
\text { and are } \\
\text { considered } \\
\text { outdated } \\
\text { - Rattan is not a } \\
\text { commodity that } \\
\text { is available } \\
\text { quickly, so it } \\
\text { requires time in } \\
\text { collecting raw } \\
\text { materials } \\
\text { - Rattan prices are } \\
\text { relatively } \\
\text { volatile, which } \\
\text { can affect the } \\
\text { income of } \\
\text { craftsmen }\end{array}$ \\
\hline
\end{tabular}




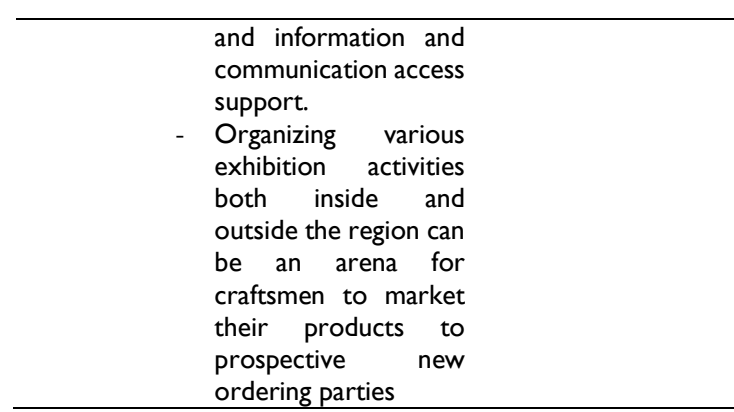

Through the results of the SWOT analysis that has been carried out, a cross-sectional analysis is prepared by paying attention to the points that are interconnected. The points are then compiled following a predetermined topic, where there are four main ideas that will be the focal point of this research, namely aspects of job training, capital support, equipment and technology assistance, and access to information and communication. These results then form the basis for the formulation of recommendations submitted in the Policy Paper or Brief Policy which are an integral part of this research. The cross-sectional results of the SWOT analysis are presented in Table 4.

Table 4. Cross-sectional analysis of the results of SWOT analysis of Small and Medium Micro Enterprises of Rattan Craftsmen in Central Kalimantan

\begin{tabular}{|c|c|c|}
\hline Number & $\begin{array}{l}\text { Points of } \\
\text { analysis }\end{array}$ & Analysis results \\
\hline $\mathrm{I}$ & Work training & $\begin{array}{l}\text { Various work trainings that have } \\
\text { been carried out by stakeholders in } \\
\text { the regions both from the Office of } \\
\text { Cooperatives and MSMEs and } \\
\text { other government agencies have } \\
\text { actually been carried out quite } \\
\text { often and can accommodate the } \\
\text { needs of craftsmen to update their } \\
\text { skills and knowledge. However, the } \\
\text { training model that has been } \\
\text { implemented is still considered to } \\
\text { be unable to accommodate the } \\
\text { needs of the craftsmen due to its } \\
\text { centralized implementation in the } \\
\text { Central Kalimantan government } \\
\text { center with a schedule that has not } \\
\text { been fully periodic. To overcome } \\
\text { this, more regular training activities } \\
\text { can be scheduled and not only } \\
\text { carried out in the City of Palangka } \\
\text { Raya as the Capital of Central } \\
\text { Kalimantan Province but also in } \\
\text { various other regions. The } \\
\text { presence of experienced skilled } \\
\text { workers in each district in Central } \\
\text { Kalimantan can be used as } \\
\text { instructors / trainers in each }\end{array}$ \\
\hline
\end{tabular}

region. One of the topics that must be intensified in the implementation of the training is the actualization of the design, considering that the motives of the rattan works themselves are relatively small and varied, so the design updates and the latest motives need to be in accordance with market demand.

2 Capital support Basically, the craftsmen did not complain about the problem of capital support because the arrival of orders was always accompanied by advances that could meet the needs for raw materials. In other words, real capital assistance is not a major issue in the development of the rattan handicraft industry. In addition to the fact that there are quite a lot of raw materials and relatively cheap prices, generally each business group already has the equipment needed to make the product so that the capital needed is mainly only used to procure rattan raw materials and other complementary materials.

3 Equipment and It must be acknowledged in terms technology of the availability of production assistance process supporting equipment from the business group, it is still not fulfilling both in terms of quantity and quality of existing equipment. The fulfillment of these equipment needs has actually been sought by the Regional Government through the related agencies from each district / city. However, the provision of such assistance is often not balanced with the control of the aid provider, so that assistance has been provided as if there is no control, it only stops until the provision of assistance. Even though ideally, the assistance was also accompanied by a monitoring mechanism that allows the assistance to be optimized by each business group and not misdirected.

Access to
information
and
communication $\quad \begin{aligned} & \text { The exhibition in Central } \\ & \text { Kalimantan has actually been done } \\ & \text { quite often, especially with regard } \\ & \text { to exhibitions of typical Central } \\ & \text { Kalimantan handicraft products } \\ & \text { such as rattan woven crafts } \\ & \text { themselves. However, the } \\ & \text { exhibitions held in Central } \\ & \text { Kalimantan are still quite rare, less } \\ & \text { than I0 times a year. Even so, the } \\ & \text { exhibition was mostly held in big } \\ & \text { cities such as Palangka Raya, } \\ & \text { Sampit, Pangkalan Bun, and Kuala } \\ & \text { Kapuas, so that craftsmen from the } \\ & \text { regions tended to have less access } \\ & \text { to exhibit their work in events that } \\ & \text { were quite far away. However, } \\ & \text { there are other alternatives for } \\ & \text { artisans to showcase their work } \\ & \text { without the need to take part in } \\ & \text { exhibitions. Among other things by } \\ & \text { displaying his work in government } \\ & \text { offices, especially in locations that }\end{aligned}$


are easily visible to government guests. As such, this will be an attractive promotion for typical Central Kalimantan works for travelers.

The implications of this study besides providing a comprehensive description of the condition of MSMEs in Central Kalimantan for rattan handicraft products, also resulted in a policy formulation that could protect all stakeholders both craftsmen as business actors and agencies related to the development of MSMEs in Central Kalimantan. Apart from the various dynamics that occur, opportunities for developing these types of businesses are still very feasible to develop. Furthermore, support from various parties involved, especially the Regional Government through related agencies, plays an important role in the development of the craft MSME industry sector.

\section{CONCLUSION}

This research has succeeded in providing a comprehensive description of the condition of MSMEs in Central Kalimantan for rattan handicraft products, which shows an interesting dynamic to be developed. Various aspects involved in developing these types of industries include support in the form of training, capital support, equipment and technology support, and support for access to information and communication. Apart from the various dynamics that have occurred for the development of MSMEs in Central Kalimantan especially for the development of the rattan handicraft industry, the opportunities for developing these types of businesses are still very feasible to develop further. Furthermore, the support of various parties involved, especially the Regional Government through related agencies, plays an important role in the development of the industry. One concrete example is the provision of training to improve the skills of handicraft business players to improve the quality of the products and the quantity of products produced. The training activities should not be carried out only occasionally but are scheduled periodically so that business people can optimize the skills acquired. The training is also expected to foster enthusiasm to produce innovations from various products produced so that they can compete with various other handicraft products. In addition, assistance in the form of production equipment such as sewing machines can also be carried out, especially for business groups that have the potential to be developed because they have a large turnover but the asset value is not too high. Nevertheless, it is necessary to implement a monitoring and evaluation mechanism for various assistance provided so that the various forms of support are not misdirected. As has happened, there are business groups that have received assistance in the form of sewing machines in sufficient quantities with the hope that the business group's turnover can increase. In fact, the business group actually experienced a sharp decline in turnover. Therefore, for business groups that experience a decline after being given such assistance, they should be given a "punishment" in the form of withdrawal of equipment assistance provided or excluded in the provision of further assistance. Access to information and communication provided by the Regional Government by involving several business groups in various exhibition activities has also been carried out intensively to market processed products that have been made to various parties. It would be good for the exhibition to not only involve local and central government parties but also involve various other business groups that are equally engaged in the MSME sector but with different types of products to attract community interests. Finally, all the efforts that have been made by the Central Kalimantan Regional Government in advancing the MSME group, especially those engaged in the rattan handicraft industry, have shown satisfactory results. Nevertheless, there is always room for change in a better direction, especially to advance the creative industry sector in Central 
Kalimantan in supporting the Kalteng Berkah or Central Kalimantan Blessing vision.

\section{ACKNOWLEDGMENT}

This research was carried out through a research grant from the Central Kalimantan Regional Planning Agency, Research and Development. The authors also thanked the Institute for Research and Community Services Universitas Muhammadiyah Palangkaraya for helping carry out this research.

\section{REFERENCES}

Baharuddin. 20I5. Bentuk-bentuk perubahan sosial dan kebudayaan. Al-Hikmah Jurnal Dakwah, 9, I80205.

Gunartin. 2017. Penguatan UMKM sebagai pilar membangun ekonomi bangsa. EDUKA Jurnal Pendidikan, Hukum dan Bisnis, I, 59-74.

Hapsari, P.P., Hakim, A., \& Soeaidy, S. 2014. Pengaruh pertumbuhan usaha kecil menengah (UKM) terhadap pertumbuhan ekonomi daerah (Studi di pemerintah Kota Batu). WACANA, Jurnal Sosial dan Humaniora, 17, 88-96.

Irawan, D. 20I5. Potensi usaha kooperasi dan usaha kecil menengah di daerah terisolir dan tertinggal. Coopetition, 6, 5I-62.

Kartini, N.H., Rahayu, Y., Rahman, A., Marjanah, S., Ramadhani, D.N.L., \& Supiyani, I. 2019. Kerajinan Tikar Purun di Kelompok Masyarakat Pimpinan Daerah Aisyiyah Kuala Pembuang Seruyan. PengabdianMu: Jurnal Ilmiah Pengabdian Kepada Masyarakat, 4, 4649.

Maimunah, S. 2017. Model Perlindungan Hutan dengan Pendekatan Pemanfaatan HHBK bagi Masyarakat Kawasan Hutan Pendidikan UM Palangkaraya. Daun: Jurnal Ilmiah Pertanian dan Kehutanan, 4, 100-108.

Masturi, A. 2010. Membangun relasi sosial melalui komunikasi empatik (Perspektif psikologi komunikasi). KOMUNIKA: Jurnal Dakwah dan Komunikasi, 4, |4-3I.

Mokalu, B.J. 2016. Revitalisasi Pantai Prahara bagi perempuan pedagang kuliner tradisional di Pantai Malalayang 2 Manado. Jurnal LPPM
Bidang EkoSosBudKum (Ekonomi, Sosial, Budaya, dan Hukum), 3, 92-105.

Nirwana, D.C., Muhammadiah, \& Hasanuddin, M. 2017. Peran pemerintah dalam pembinaan usaha kecil menengah di Kabupaten Enrekang. Kolaborasi: Jurnal Administrasi Publik, 3, I-I4.

Putra, T.G. 2015. Peran pemerintah daerah dan partisipasi pelaku usaha dalam pengembangan UMKM manik-manik kaca di Kabupaten Jombang. Kebijakan dan Manajemen Publik, 3, $1-10$.

Setyanto, A.R., Samodra, B.R., \& Pratama, Y.P. 2015. Kajian strategi pemberdayaan UMKM dalam menghadapi perdagangan bebas Kawasan ASEAN (Studi kasus Kampung Batik Laweyan). Etikonomi, I4, 205-220.

Sulastri, L. 2016. Manajemen Usaha Kecil Menengah, Bandung: LGM - LaGood's Publising, p. 22.

Utama, D.D.T. \& Darwanto. 20I3. Pengembangan usaha mikro kecil dan menengah (UMKM) berbasis kreatif di Kota Semarang. Diponegoro Journal of Economics, 2, I-I3.

Wahdah, R., \& Amalia, H.S. 2016. Pengembangan daya saing produk pada sentra kerajinan purun di Kabupaten Hulu Sungai Utara Kalimantan Selatan. SPREAD Jurnal Ilmiah Bisnis dan Keuangan, 6, 89-99.

Wardani, S. 2017. Kebijakan perizinan pengembangan UMKM sebagai upaya mewujudkan negara kesejahteraan di era liberisasi ekonomi global. In Prosiding Seminar Nasional "Perizinan sebagai Instrumen Peningkatan Kesejahteraan Masyarakat di Era Industrialisasi (Citizen Friendly), |22-14I.

Widyaningrum, N., Dewayanti, R., Chotim, E.E., \& Sadoko, I. 2003. Pola-pola Eksploitasi terhadap Usaha Kecil. Bandung: Akatiga Pusat Analisis Sosial. p. 6. 